\title{
Effects of Selenium on Photosynthetic Characteristics of Tomato Seedlings
}

\author{
Liming Wang ${ }^{1, a}$, Guochao Sun ${ }^{2, b}$ and Yi Tang ${ }^{2, c *}$ \\ ${ }^{1}$ College of Horticulture, Sichuan Agricultural University, Chengdu, Sichuan, China \\ ${ }^{2}$ Institute of Pomology and Olericulture, Sichuan Agricultural University, Chengdu, Sichuan, China \\ a1456155763@qq.com, b6183090@qq.com, '95459425@qq.com
}

${ }^{*}$ Corresponding author. Liming Wang and Guochao Sun contributed equally to this work.

Key words: Selenium; Tomato seedlings; Photosynthetic characteristics

Abstract: A pot experiment was conducted to study the effects of different concentrations selenium (Se) on the photosynthetic characteristics of tomato seedlings. The results showed that the photosynthetic parameters and photosynthetic pigment content of tomato seedlings increased first and then decreased, and reached the maximum at $5 \mathrm{mg} / \mathrm{kg}$ Se concentration. Compared with control, tomato plant height, stem diameter and root length increased by $35.44 \%, 20.59 \%$ and $85.40 \%$, respectively, net photosynthetic rate, stomatal conductance, intercellular $\mathrm{CO}_{2}$ concentration and transpiration rate increased by $22.80 \%, 25.27 \%, 0.48 \%$ and $15.38 \%$, respectively, chlorophyll a increased by $50.81 \%$, chlorophyll b increased by $57.53 \%$, total chlorophyll increased by $52.60 \%$ and carotenoid increased by $37.30 \%$. In conclusion, the optimal concentration of Se was $5 \mathrm{mg} / \mathrm{kg}$, the net photosynthetic rate and stomatal conductance of tomato seedlings were increased, the content of photosynthetic pigment was increased, and the growth of tomato seedlings was promoted.

\section{Introduction}

Selenium (Se) is one of relatively rare element, and it is also a necessary trace element for human and animal body to maintain health [1]. $72 \%$ of the regions in China belong to low Se and Se deficiency zones [2], Se deficiency can cause a variety of human or animal diseases, such as Kashin-Beck disease, Keshan disease [3-4], Inadequate intake of Se will seriously affect people's health [5-7]. With the development of science and society, the application of Se in agriculture has been paid more and more attention in the world, the studies have shown that a moderate concentration of Se can promote plant growth, excessive inhibition of plant growth, serious harm, and it has been proved in Cryptotaenia japonica [8], lettuce [9], potato [10]. In the study of cauliflower [11] and rape [12], it was found that different Se concentration could affect the chlorophyll content of plants, which showed the phenomenon of low concentration promotion and high concentration inhibition. The effects of Se on physiological characteristics, Se content and quality of garlic were studied by Xia et al. [13]. The effects of Se on the photosynthetic characteristics of tomato seedlings were studied by pot experiment in order to find the best concentration for promoting tomato photosynthesis.

\section{Materials and Methods}

Materials. The soil was taken from farmland around Sichuan agricultural university (Chengdu campus) and was sandy loam soil. Its basic physical and chemical properties were $\mathrm{pH}$ 6.29, organic matter $21.16 \mathrm{~g} / \mathrm{kg}$, total nitrogen $1.09 \mathrm{~g} / \mathrm{kg}$, total phosphorus $1.2 \mathrm{~g} / \mathrm{kg}$, total potassium $22 \mathrm{~g} / \mathrm{kg}$, available phosphorus $16.22 \mathrm{mg} / \mathrm{kg}$ and available potassium $156.2 \mathrm{mg} / \mathrm{kg}$. After retrieving it, spread it flat and dry it for one week, screened it with $1 \mathrm{~cm}$ sieve, and set aside. Red cherry tomato seeds were collected from Sichuan Agricultural University. The $\mathrm{Na}_{2} \mathrm{O}_{3} \mathrm{Se} \cdot 5 \mathrm{H}_{2} \mathrm{O}$ purchased from Chengdu Kelong chemical reagent factory.

Experimental Design. The experiment was conducted in Sichuan Agricultural University (Chengdu Campus) from April to July, 2017. In April 2017, the soil was air-dried, crushed, evenly 
mixed, screened by a $5 \mathrm{~mm}$ sieve, weighed $3.0 \mathrm{~kg}$ respectively and placed in a plastic basin of 15 $\mathrm{cm} \times 18 \mathrm{~cm}$ (high $\times$ diameter), added with analytical pure $\mathrm{Na}_{2} \mathrm{CO}_{3} \cdot 5 \mathrm{H}_{2} \mathrm{O}$ solution, and the Se concentration was $0,5,10,25 \mathrm{mg} / \mathrm{kg}$, and fully mixed with the soil, and naturally placed for balance for 4 weeks before mixing again for later use. When the three leaves of tomato seedlings were unfolded, the tomato seedlings with uniform growth were selected, three plants were planted in each pot with 4 treatments, and each treatment was repeated 3 times. After 30 days, the plants were harvested.

Index Measurement Method. The plant height and root length were measured with a ruler with a precision of $\mathrm{mm}$, the stem diameter was measured with vernier caliper, and the photosynthetic pigment content (chlorophyll a, chlorophyll $\mathrm{b}$, total chlorophyll content and carotenoid) was measured with acetone-ethanol mixture (1:1) extraction. Photosynthesis was measured by Li-6400 portable photosynthetic apparatus (Li-cor Inc., USA) and began at 9 a.m. The photosynthetic rate $(\mathrm{Pn})$, transpiration rate $(\mathrm{Tr})$, stomatal conductance $(\mathrm{Gs})$ and intercellular $\mathrm{CO}_{2}$ concentration $(\mathrm{Ci})$ were measured by controlling the concentration of $\mathrm{CO}_{2}$ at $400 \mu \mathrm{molCO} \mathrm{C}_{2} / \mathrm{mol}$, temperature at $25 \square$ and illumination intensity at $1000 \mu \mathrm{mol} / \mathrm{m}^{2} / \mathrm{s}$.

Statistics analyses. Using Excel 2010 for data recording and finishing, SPSS 20.0 was used for statistical analysis, compare of different significance using Duncan's new multiple range method.

\section{Results and Analysis}

Growth of Tomato Seedlings. It can be seen from table 1, that with the increase of Se concentration, the plant height, stem diameter, root length, root fresh weight and fresh weight of aboveground of tomato seedling increased first and then decreased. The plant height, stem diameter, root length, root fresh weight and aboveground fresh weight of tomato increased by $35.44 \%$ ( $P<$ 0.05), 20.59\% $(P<0.05), 85.40 \%(P<0.05), 94.46 \%(P<0.05)$ and $35.62 \%(P<0.05)$ respectively compared with control under Se concentration of $5 \mathrm{mg} / \mathrm{kg}$. Tomato plant height and root length increased significantly compared with control by $11.97 \%(P<0.05)$ and $76.28 \%(P<$ $0.05)$, respectively, while stem diameter, root fresh weight and aboveground fresh weight did not increase significantly under $10 \mathrm{mg} / \mathrm{kg}$, however, at the $25 \mathrm{mg} / \mathrm{kg}$ Se concentration, the plant height, stem diameter, root fresh weight and aboveground fresh weight decreased significantly compared with control except that the root length of tomato increased significantly, which decreased by $17.41 \%(P<0.05), 17.85 \%(P<0.05), 52.51 \%(P<0.05)$ and $68.39 \%(P<0.05)$.

Table 1 Growth of tomato seedlings

\begin{tabular}{|c|c|c|c|}
\hline $\begin{array}{c}\text { Se concentration } \\
(\mathrm{mg} / \mathrm{kg})\end{array}$ & $\begin{array}{c}\text { Plant height } \\
(\mathrm{cm})\end{array}$ & $\begin{array}{c}\text { Stem diameter } \\
(\mathrm{cm})\end{array}$ & $\begin{array}{c}\text { Root length } \\
(\mathrm{cm})\end{array}$ \\
\hline 0 & $64.333 \pm 3.194 \mathrm{c}$ & $0.437 \pm 0.010 \mathrm{~b}$ & $20.100 \pm 0.872 \mathrm{c}$ \\
\hline 5 & $87.133 \pm 2.371 \mathrm{a}$ & $0.527 \pm 0.025 \mathrm{a}$ & $37.267 \pm 1.350 \mathrm{a}$ \\
\hline 10 & $72.033 \pm 0.306 \mathrm{~b}$ & $0.454 \pm 0.007 \mathrm{~b}$ & $35.433 \pm 0.569 \mathrm{a}$ \\
\hline 25 & $53.133 \pm 4.596 \mathrm{~d}$ & $0.359 \pm 0.022 \mathrm{c}$ & $24.600 \pm 1.778 \mathrm{~b}$ \\
\hline
\end{tabular}

Note: The data followed by different lowercase indicate significant difference of $5 \%$ level, the same as follow tables.

Photosynthetic Parameters of Tomato Seedlings. As can be seen from Table 2, the net photosynthetic rate of tomatoes increased by $22.80 \%(P<0.05)$ and $1.87 \%(P>0.05)$ at $5 \mathrm{mg} / \mathrm{kg}$ and $10 \mathrm{mg} / \mathrm{kg}$ compared with control, the net photosynthetic rate of tomato decreased under the Se concentration of $25 \mathrm{mg} / \mathrm{kg}$. The stomatal conductance of tomato increased significantly by $25.27 \%$ $(P<0.05)$ at $5 \mathrm{mg} / \mathrm{kg}$ and decreased significantly by $26.92 \%(P<0.05)$ at $10 \mathrm{mg} / \mathrm{kg}$ compared with control. The intercellular $\mathrm{CO}_{2}$ concentration of tomato increased under $5 \mathrm{mg} / \mathrm{kg}$, but not significant, the other two treatments all decreased, and the intercellular $\mathrm{CO}_{2}$ concentration of tomato decreased significantly by $9.75 \%(P<0.05)$ compared with control under $10 \mathrm{mg} / \mathrm{kg}$. The transpiration rate increased significantly at $5 \mathrm{mg} / \mathrm{kg}$, increased by $15.38 \%(P<0.05)$ compared with control, and decreased at 10 and $25 \mathrm{mg} / \mathrm{kg}$, reached a significant level under the Se concentration of $10 \mathrm{mg} / \mathrm{kg}$, 
decreased by $24.03 \%(P<0.05)$ compared with control.

Table 2 Photosynthetic parameters of tomato seedlings

\begin{tabular}{|c|c|c|c|c|}
\hline $\begin{array}{c}\text { Se concentration } \\
(\mathrm{mg} / \mathrm{kg})\end{array}$ & $\begin{array}{c}\text { Net } \\
\text { photosynthetic } \\
\text { rate } \\
\left(\mu \mathrm{mol} \mathrm{CO} / \mathrm{m}^{2} / \mathrm{s}\right)\end{array}$ & $\begin{array}{c}\text { Stomatal } \\
\text { conductance } \\
\left(\mathrm{mol} \mathrm{H}_{2} \mathrm{O} / \mathrm{m}^{2} / \mathrm{s}\right)\end{array}$ & $\begin{array}{c}\text { Intercellular } \mathrm{CO}_{2} \\
\text { concentration } \\
\left(\mathrm{mmol} \mathrm{CO}_{2} / \mathrm{mol}\right)\end{array}$ & $\begin{array}{c}\text { Transpiration rate } \\
\left(\mathrm{mol} \mathrm{H}_{2} \mathrm{O} / \mathrm{m}^{2} / \mathrm{s}\right)\end{array}$ \\
\hline 0 & $8.601 \pm 0.281 \mathrm{~b}$ & $0.182 \pm 0.025 \mathrm{~b}$ & $305.850 \pm 9.527 \mathrm{a}$ & $3.108 \pm 0.314 \mathrm{~b}$ \\
\hline 5 & $10.562 \pm 0.397 \mathrm{a}$ & $0.228 \pm 0.030 \mathrm{a}$ & $307.332 \pm 3.230 \mathrm{a}$ & $3.586 \pm 0.339 \mathrm{a}$ \\
\hline 10 & $8.762 \pm 0.462 \mathrm{~b}$ & $0.133 \pm 0.038 \mathrm{c}$ & $276.026 \pm 2.827 \mathrm{~b}$ & $2.361 \pm 0.408 \mathrm{c}$ \\
\hline 25 & $8.217 \pm 0.344 \mathrm{~b}$ & $0.155 \pm 0.011 \mathrm{bc}$ & $296.882 \pm 2.287 \mathrm{a}$ & $2.819 \pm 0.094 \mathrm{~b}$ \\
\hline
\end{tabular}

Photosynthetic Pigment Content Tomato Seedlings. From Table 3, it was found that chlorophyll a, chlorophyll $\mathrm{b}$, total chlorophyll content and carotenoid content were higher than that of control, Chlorophyll a, chlorophyll b, total chlorophyll and carotenoid content increased compared with control, showing a trend of increasing first and then decreasing. Compared with control, chlorophyll a increased by $50.81 \%(P<0.05), 13.44 \%(P<0.05)$ and $5.71 \%(P>0.05)$, Chlorophyll b increased $57.53 \%(P<0.05), 13.47 \%(P<0.05)$ and $4.34 \%(P>0.05)$, The total chlorophyll content increased by $52.60 \%(P<0.05), 13.51 \%(P<0.05)$ and $5.43 \%(P>0.05)$ and the content of carotenoid increased by $37.30 \%(P<0.05), 8.68 \%(P>0.05)$ and $4.50 \%(P>0.05)$, respectively. The content of chlorophyll a, chlorophyll $\mathrm{b}$, total chlorophyll and carotenoid in tomato increased compared with the control by $50.81 \%, 57.53 \%, 52.60 \%$ and $37.30 \%$ respectively under the Se concentration of $5 \mathrm{mg} / \mathrm{kg}$.

Table 3 Photosynthetic pigment content in tomato seedlings

\begin{tabular}{|c|c|c|c|c|c|}
\hline $\begin{array}{c}\text { Se } \\
\text { concentration } \\
(\mathrm{mg} / \mathrm{kg})\end{array}$ & $\begin{array}{c}\text { Chlorophyll a } \\
(\mathrm{mg} / \mathrm{g})\end{array}$ & $\begin{array}{c}\text { Chlorophyll b } \\
(\mathrm{mg} / \mathrm{g})\end{array}$ & $\begin{array}{c}\text { Total } \\
\text { chlorophyll } \\
(\mathrm{mg} / \mathrm{g})\end{array}$ & $\begin{array}{c}\text { Chlorophyll } \\
\mathrm{a} / \mathrm{b}\end{array}$ & $\begin{array}{c}\text { Carotenoid } \\
(\mathrm{mg} / \mathrm{g})\end{array}$ \\
\hline 0 & $1.295 \pm 0.045 \mathrm{c}$ & $0.438 \pm 0.038 \mathrm{c}$ & $1.732 \pm 0.073 \mathrm{c}$ & 2.958 & $0.311 \pm 0.020 \mathrm{~b}$ \\
\hline 5 & $1.953 \pm 0.086 \mathrm{a}$ & $0.690 \pm 0.042 \mathrm{a}$ & $2.643 \pm 0.127 \mathrm{a}$ & 2.832 & $0.427 \pm 0.017 \mathrm{a}$ \\
\hline 10 & $1.469 \pm 0.058 \mathrm{~b}$ & $0.497 \pm 0.098 \mathrm{~b}$ & $1.966 \pm 0.119 \mathrm{~b}$ & 2.956 & $0.338 \pm 0.053 \mathrm{~b}$ \\
\hline 25 & $1.369 \pm 0.057 \mathrm{bc}$ & $0.457 \pm 0.054 \mathrm{bc}$ & $1.826 \pm 0.111 \mathrm{bc}$ & 2.995 & $0.325 \pm 0.037 \mathrm{~b}$ \\
\hline
\end{tabular}

\section{Conclusion}

The photosynthetic characteristics of tomato seedlings were affected by applying different concentrations of $\mathrm{Se}$ in soil, which showed a trend of increasing first and then decreasing. Compared with control, tomato seedling height, stem diameter, root length, net photosynthetic rate, stomatal conductance, transpiration rate, chlorophyll a, chlorophyll b, total chlorophyll and carotenoids increased significantly and reached the maximum value at the Se concentration of 5 $\mathrm{mg} / \mathrm{kg}$, and the effect was better than the other three treatments.

\section{References}

[1] M. Chen and J.A. Tan: Progress in Soil Science Vol. 22 (1994), p. 1.

[2] D.X. Zheng, R.B. Li and W.Y. Wang: Journal of Environmental Science Vol. 2 (1982), p. 241.

[3] A.L. Martin: American Journal of Botany Vol. 23 (1936), p. 471.

[4] J.Y. Li, S.X. Ren and D Z Chen: Journal of Environmental Sciences Vol. 2 (1982), p. 91.

[5] Y.Q. Wang, J.S. Cao, J.H. Li, M. Zhao and G.F. Zhao: Acta Horticulturae Sinica Vol. 28 (2001), p. 425. 
[6] C.D. Thomson: European Journal of Clinical Nutrition Vol. 58 (2004), p. 391.

[7] A. Haug, R.D. Graham, O.A. Christophersen and H.L. Graham: Microbial Ecology in Health and Disease Vol. 19 (2007), p. 209.

[8] L.L. Chang, S.B. Zhou, T.C. Chao, Y.J. Huang, C.F. Tang and Q.K. Zhou: Journal of Soil and Water Conservation Vol. 27 (2013), p. 157.

[9] B. Pezzarossa, G. Petruzzelli, F. Petacco, F. Malorqio and T. Ferri: Chemosphere Vol. 67 (2007), p. 322.

[10]M. Turakainen, H. Hartikainen and M.M. Seppanen: Journal of Agricultural \& Food Chemistry Vol. 52 (2004), p. 5378.

[11]D.Z. Zhou, Q.Y. Tang, C. Zhang and Y.X. Wu: Hubei Agricultural Sciences Vol. 12 (2005), p. 77-78.

[12]C. Zhang, Y.X. Wu and Z.K. Peng: Journal of Hubei Institute for Nationalities (Natural Sciences) Vol. 20 (2002), p. 63.

[13] Y.X. Xia, S.Q. Liu, H. Li and X.W. Chen: Plant Nutrition and Fertilizer Science Vol. 18 (2012), p. 733. 